\title{
6
}

\section{ELF-AWARENESS AND INTERCULTURAL COMMUNICATIVE COMPETENCE IN ELT POLICIES IN PORTUGAL}

\section{TOMADA DE CONSCIÊNCIA SOBRE ILF E COMPETÊNCIA COMUNICATIVA INTERCULTURAL NAS POLÍTICAS DE ENSINO DE LÍNGUA INGLESA (ELI) EM PORTUGAL}

\author{
Luís Guerra ${ }^{1}$ \\ Universidade de Évora, Portugal
}

\begin{abstract}
This study attempts to examine to what extent the concepts of Intercultural Communicative Competence and English as a Lingua Franca are theoretically and practically formulated in some of the most recently implemented European and Portuguese English language teaching documents and, if so, how they are framed to be put into practice in the English language classroom. Overall, the documents analyzed-the Common European Framework of Reference for Languages (2001), the CEFR Companion Volume with New Descriptors (2018), both published by the Council of Europe, and the Essential Learnings (2018), introduced by the Portuguese Ministry of Education-display traditional approaches to the development of intercultural (communicative) competence in the English language classroom failing to truly and consistently represent the current role of English as an international lingua franca.
\end{abstract}

Keywords: Intercultural Communicative Competence; ELF; ELF-Awareness; English Language Teaching; Language Policy.

$1 \quad 1$ spg@uevora.pt 
Resumo: Este estudo propõe-se a examinar até que ponto os conceitos de Competência Comunicativa Intercultural e Inglês como Língua Franca são apresentados, de forma teórica e prática, em alguns dos documentos no âmbito do ensino e aprendizagem da língua inglesa, mais recentemente implementados, na Europa e em Portugal. De um modo geral, os documentos analisados, o Quadro Europeu Comum de Referência para as Línguas: Aprendizagem, Ensino, Avaliação (2001), o CEFR Companion Volume with New Descriptors (2018), ambos publicados pelo Conselho da Europa, e as Aprendizagens Essenciais (2018), propostas pelo Ministério da Educação português, apresentam abordagens tradicionais ao desenvolvimento da competência (comunicativa) intercultural na sala de aula de língua inglesa, falhando em introduzir, de forma autêntica e consistente, o papel atual do inglês como língua franca internacional.

Palavras-Chave: Competência Comunicativa Intercultural; ILF; Consciência de ILF; Ensino de Língua Inglesa; Política Linguística

\section{INTRODUCTION}

Over the past thirty years, the field of English language teaching (ELT) has encouraged lively debates over two of the most thought-provoking and central issues in applied linguistics. On the one hand, the spread of English in international contexts and in diverse domains, such as in mass media, international relations, research, popular culture, among several others, has increased relevance of the role of the non-native speaker as most international communicative exchanges generally take place among non-native speakers of English (GRADDOL, 1997). Defined as "a 'contact language' between persons who share neither a common native tongue nor a common (national) culture, and for whom English is the chosen foreign language of communication" (FIRTH, 1996, p. 240), early research on English as a Lingua Franca (ELF) focused on its linguistic features (COGO; DEWEY, 2012; PITZL, 2012) and on ELF corpora (MAURANEN, 2012; SEIDLHOFER, 2011). More recent studies on ELF have directed their attention to various areas of research such as descriptive studies on ELF, students' perception of ELF, teaching and learning in ELF contexts (GUERRA; BAYYURT, 2019) and ELF-awareness in pre- and in-service teacher education (KURT; CAVALHEIRO; PEREIRA, 2019).

The other pivotal issue of debate in applied linguistics is the concept of intercultural communicative competence (ICC). Broadly speaking, ICC may be explained as someone's capacity to understand cultures, as well as his/her own, and be able to make use of that understanding to communicate successfully with people from different cultural contexts. As Byram (1997, p. 7) states, it is the "ability to communicate and interact across linguistic and cultural borders appropriately and efficiently." As a result of the significance of ICC in language 
teaching and teacher education, several areas of research focusing on ICC have been identified: the theoretical grounds of ICC; strategies, activities or materials aiming at developing the learners' ICC; student-based research; and ICC in preor in-service teacher education (GUERRA; GONÇALVES, 2019).

The aim of this chapter is to ascertain if the concepts of ICC and ELF are theoretically and practically introduced in some of the most recently produced European and Portuguese ELT documents and, if so, how they are suggested, formulated and framed to be applied in the English language classroom. To do so, the following sections will briefly present the main practical and theoretical aspects related to ICC and ELF.

\section{INTERCULTURAL COMMUNICATIVE COMPETENCE}

As previously defined, Spitzberg and Chagnon (2009, p. 7) describe ICC as "the appropriate and effective management of interaction between people who, to some degree or another, represent different or divergent cognitive, affective, and behavioral orientations to the world." Byram (1997, p. 71) makes a major distinction between intercultural communicative competence and intercultural competence (IC). On the one hand, IC refers to people's "ability to interact in their own language with the people from another country and culture," while, on the other hand, ICC takes into account language teaching and stresses "the ability to interact with people from another country and culture in a foreign language." For Byram, someone who has acquired ICC is able to build relationships while using the foreign language, effectively communicating, considering his/hers and the other's needs and points of view.

Research on ICC has endeavored to build models based on attitudes, beliefs and skills to determine successful intercultural communication (BYRAM; MORGAN, 1994; SHUANG, 2012; SPITZBERG; CHANGNON, 2009). Byram and Morgan (1994) recommend a three-dimension model (knowledge, attitudes and behavior) to measure ICC in foreign language education. Regarding the 'knowledge dimension,' Byram and Morgan suggest that in order to successfully communicate interculturally, learners must possess factual knowledge (i.e. historical and geographical facts, facts about the society such as its ceremonies and institutions). As for the 'attitudes dimension', students need to develop positive attitudes towards language learning as well as people from other 
countries. Lastly, the 'behavior dimension' should not be restricted to being polite, or following etiquette when dealing with people from other cultures.

Admittedly, one of the main problems in ICC is to explain how it is developed. In language teaching practices it is evident that there is usually an easy and uncomplicated choice of teaching facts or institutions of a society (the 'knowledge dimension'). Research has demonstrated that teachers are inclined to focus on factual information (i.e. holidays, traditions, food, etc.) and not on the pragmatic and sociolinguistic competences needed for the intercultural speaker (REID, 2014). Nonetheless, it is crucial to develop and change attitudes and behavior. Also, teachers seem to avoid incorporating materials on intercultural awareness (MUGHAN, 1999) even though research has highlighted the importance of developing teachers' and learners' reflective attitudes towards intercultural learning (CORTAZZI; JIN, 1999). Thus, rather than merely conveyed in the language classroom, attitudes and skills are aspects that have to be acquired and built up, as the classroom is a privileged space for that to happen.

Alptekin (2002) calls attention to another main issue in the development of ICC which is related to the role of English as an international lingua franca in the $21^{\text {st }}$ century. For Alptekin,

the conventional model of communicative competence, with its strict adherence to native speaker norms within the target language culture, would appear to be invalid in accounting for learning and using an international language in cross-cultural settings. A new pedagogic model is urgently needed to accommodate the case of English as a means of international and intercultural communication (2002, p. 63).

Similarly, Byram (1997) considers three possible situations in intercultural communication: (1) between people of different languages and countries where one is a native speaker of the language used; (2) between people of different languages and countries where the language used is a lingua franca; and (3) between people of the same country but different languages, one of whom is a native speaker of the language used. Therefore, it is quite clear how these two concepts, ICC and ELF, are interconnected. Most importantly, it is crucial to perceive how they are translated into the foreign language classroom policies and practices. 


\section{ELF AND ELF-AWARENESS IN ELT}

Jenkins (2013, p. 2) provides a concise but clear definition of ELF when she states that it "refers, in a nutshell, to the world's most extensive contemporary use of English, in essence, English when it is used as a contact language between people from different first languages (including native English speakers)." More specifically, House (1999, p. 74) focuses on the intercultural nature of ELF interactions when she says that these "are defined as interactions between members of two or more different linguacultures in English, for none of whom English is the mother tongue."

Such view of ELF interactions is supported by Lwin and Marlina (2018) when they call attention to the role of English as a global language in the $21^{\text {st }}$ century and its implications to the foreign language classroom in terms of the students' linguistic and cultural diversity. Therefore, teachers should re-examine their teaching goals when dealing with the traditional Standard English/native norms and cultures paradigm. Sifakis and Bayyurt (2015, p. 474) suggest that teachers should "become owners of ELF, as they come to appreciate it through linking it to their individual teaching and learning contexts and specifications." Put simply, English language teachers should possess knowledge and understanding of the lingua franca use of the language and the consequences to the language classroom, such as how to approach language ownership, norms, models and varieties, the status of the native speaker and the native speaker teacher, and the role of culture.

In other words, teachers should be aware of "the needs and wants of their learners, the target situation, the curriculum, the textbooks selected" (SIFAKIS ET AL., 2018, p. 57). The notion of ELF-awareness (BAYYURT; SIFAKIS, 2015a, 2015b; SIFAKIS, 2017) becomes clear when Kurt, Cavalheiro and Pereira (2019, p. 434) state that "if the aim is for teachers to become ELF-aware, they need to be critically engaged not only with the research literature on ELF, but also reflect upon how the concept may be applied to their own teaching contexts."

The following sections will briefly describe the Portuguese educational context and the European and Portuguese ELT documents which were analysed for this study. 


\section{THE PORTUGUESE ELT CURRICULUM}

The Comprehensive Law on the Education System (CLES) (1999) approved in October 1986 is a key document as it establishes the general framework for the Portuguese educational system and, more specifically, the structural measures in the reform of both basic and secondary education. The CLES establishes that basic education consists of three consecutive ciclos, the $1^{\text {st }}$ lasting for four years, the $2^{\text {nd }}$ for two years, and the $3^{\text {rd }}$ for three years. Secondary education courses, on the other hand, last for three years (see Table 1 below):

\begin{tabular}{|c|c|c|c|}
\hline Year 12 & \multirow{3}{*}{$\begin{array}{l}\text { Secondary } \\
\text { Education }\end{array}$} & \multirow{3}{*}{$\begin{array}{l}\text { Scientific- } \\
\text { humanistic } \\
\text { Courses }\end{array}$} & \multirow{3}{*}{$\begin{array}{c}\text { Technological } \\
\text { Courses }\end{array}$} \\
\hline Year 11 & & & \\
\hline Year 10 & & & \\
\hline Year 9 & \multirow{9}{*}{$\begin{array}{c}\text { Basic } \\
\text { Education }\end{array}$} & \multirow{3}{*}{\multicolumn{2}{|c|}{ 3rd ciclo }} \\
\hline Year 8 & & & \\
\hline Year 7 & & & \\
\hline Year 6 & & \multirow{2}{*}{\multicolumn{2}{|c|}{ 2nd ciclo }} \\
\hline Year 5 & & & \\
\hline Year 4 & & \multirow{4}{*}{\multicolumn{2}{|c|}{ 1st ciclo }} \\
\hline Year 3 & & & \\
\hline Year 2 & & & \\
\hline Year 1 & & & \\
\hline
\end{tabular}

Table 1: The Portuguese educational system

As far as the English syllabi proposed for all educational levels are concerned, in the case of primary education $\left(1^{\text {st }} \text { ciclo, Years } 1-4\right)^{2}$, emphasis is given to listening and speaking skills. Also, the students' awareness of linguistic and cultural diversity in general are promoted. At lower and upper basic education ( $2^{\text {nd }}$ and $3^{\text {rd }}$ ciclos, Years 5-9), attention is also placed on developing students' awareness of linguistic and cultural diversity. In upper basic education, further consideration is given to Portuguese culture and language. References to British and American cultures are quite common but explicit allusions to British and American English are less frequent. The secondary level syllabi (Years 10-12) focus on other concerns in line with a more unrestricted view of English(es) by establishing the learning of English within a multilingual and multicultural European and international setting. So, considering the different syllabi, all share

2 English is a mandatory subject from Year 3; in Years 1 and 2 it is provided as an elective subject. 
the need to improve learners' knowledge and awareness of their own sociocultural universe and to demonstrate their appreciation for other cultures.

The relevance of focusing on the learners' respect for other cultures is even greater as Portugal has become a multicultural society over the past years. According to the Portuguese Migration Observatory (OLIVEIRA; GOMES, 2017), in 2017 there were 421,711 foreigners of over 180 nationalities. Among them, 38,712 foreign students were enrolled from basic to secondary education in the school year 2016-2017. Although the majority of these students $(21,283)$ come from Portuguese-speaking countries such as Brazil, Cape Verde, Guinea-Bissau, Angola and São Tomé and Príncipe, there is a considerable number of citizens from Eastern Europe $(7,201)$ such as Ukraine, Moldova, Romania, Bulgaria and Russia, as well as from Western Europe $(2,557)$ such as the UK, France, Spain and Germany. Finally, there is also a considerable amount of students from China $(1,149)$.

However, before the analysis to identify if the concepts of ICC and ELF are theoretically and practically introduced in some Portuguese ELT documents, it is significant to briefly examine some current European foreign language teaching documents, such as the Common European Framework of Reference for Languages (CEFR) (2001) and the CEFR Companion Volume with New Descriptors (2018).

\section{THE COMMON EUROPEAN FRAMEWORK OF REFERENCE FOR LANGUAGES (CEFR)}

The Common European Framework of Reference for Languages: Learning, Teaching, Assessment (CEFR) was created following a thorough process of drafting, piloting and consultation. The main aims of the CEFR (2001, p. 5-6) are threefold: to promote and facilitate co-operation among educational institutions in different countries; to provide a sound basis for the mutual recognition of language qualifications; and to assist learners, teachers, course designers, examining bodies and educational administrators to situate and co-ordinate their efforts. In other words, the CEFR intends to stimulate reflection on objectives and methods, to facilitate communication and to provide a common basis for curriculum development, the ellaboration of syllabi, examinations and qualifications.

One of the core issues underlying the CEFR is the concept of plurilingualism. However, this document stresses that "plurilingualism has itself 
to be seen in the context of pluriculturalism. Language is not only a major aspect of culture, but also a means of access to cultural manifestations" (COUNCIL OF EUROPE, 2001, p. 6). Moreover, the CEFR puts forward that

in a person's cultural competence, the various cultures (national, regional, social) to which that person has gained access do not simply co-exist side by side; they are compared, contrasted and actively interact to produce an enriched, integrated pluricultural competence, of which plurilingual competence is one component, again interacting with other components. (IBIDEM, 2001, p. 6)

However, even though this document emphasizes the importance of plurilingualism and pluriculturalism, the three principal dimensions of the CEFR-language activities, the domains in which they occur, and the competences on which we draw when we engage in them-do not provide specific information about those two concepts. It was only with the publishing of the CEFR Companion Volume that this gap was filled.

\section{THE CEFR COMPANION VOLUME WITH NEW DESCRIPTORS $(\mathrm{CEFR} / \mathrm{CV})^{3}$}

The CEFR/CV is intended as a complement to the CEFR. Thus, the central aim of CEFR/CV is to update the CEFR illustrative descriptors by: (1) highlighting certain innovative areas of the CEFR for which no descriptor scales had been provided in the 2001 set of descriptors, but which have become increasingly relevant over the past twenty years, especially mediation and plurilingual/pluricultural competence; (2) building on the successful implementation and further development of the CEFR, for example by more fully defining 'plus levels' and a new 'Pre-A1' level; (3) responding to demands for more elaborate description of listening and reading in existing scales, and for descriptors for other communicative activities such as online interaction, using telecommunications, expressing reactions to creative text and literature; and (4) enriching the description at A1, and at the C levels, particularly $\mathrm{C} 2$.

More specifically, the CEFR/CV proposes new illustrative level descriptors for areas such as mediation, online interaction, plurilingual and pluricultural

Available at: <https://www.coe.int/en/web/education/-/the-cefr-companion-volume-withnew-descriptors-is-now-available-online-?desktop=false>. Access: March 12, 2019 
competences. As far as pluriculturalism is concerned, in the development of the descriptors for plurilingual and pluricultural competence, the CEFR/CV (2018, p. 158) considers the following elements in order to build intercultural competence, such as:

- the need to deal with ambiguity when faced with cultural diversity, adjusting reactions, modifying language, etc.;

- the need for understanding that different cultures may have different practices and norms, and that actions may be perceived differently by people belonging to other cultures;

- the need to take into consideration differences in behaviors (including gestures, tones and attitudes), discussing over-generalizations and stereotypes;

- the need to recognize similarities and use them as a basis to improve communication;

- the will to show sensitivity to differences;

- readiness to offer and ask for clarification: anticipating possible risks of misunderstanding.

Finally, the CEFR/CV reinforces a wider perspective of language education and the native-speaker paradigm as previously proposed by the CEFR when it states that language education is "no longer seen as simply to achieve 'mastery' of one or two, or even three languages, each taken in isolation, with the 'ideal native speaker' as the ultimate model. Instead, the aim is to 'develop a linguistic repertory, in which all linguistic abilities have a place" (CEFR Section 1.3, p. 5) (CEFR Companion Volume with New Descriptors, p. 157).

\section{ELT POLICIES IN PORTUGAL: THE ESSENTIAL LEARNINGS ${ }^{4}$}

The Essential Learnings (EL) ${ }^{5}$ are curricular guidance documents for planning, implementing and assessing teaching and learning and aim at fostering

4 The following information about the Essential Learnings was taken from the website of the Directorate-General for Education of the Portuguese Ministry of Education. Availabe at: $<w w w . d g e . m e c . p t / a p r e n d i z a g e n s-e s s e n c i a i s-0>$ and <www.dge.mec.pt/aprendizagensessenciais>. Access: March 18, 2019. The original text is in Portuguese and was translated into English by the author for the purpose of this study.

5 The EL for Basic Education were approved in July 2018. Available at: <www.dge.mec.pt/aprendizagens-essenciais-ensino-basico>. Access: March 18, 2019. The EL 
the development of the areas of competence identified in the 'Students Output Profile in Compulsory Education'.

The need to redefine the Basic and Secondary Education Curricula lead to the 'Students Output Profile in Compulsory Education' as well as to the establishment of the EL. The Students Profile provided guidance to the EL and both documents are horizontally and vertically linked.

The EL are the common curricular denominator for all learners but they do not reduce what learners can do throughout the school year. Moreover, they are not the basic requirements for the learner's approval. The EL free up curricular space so that each school may develop articulated work among the EL and other learnings determined in the other documents, through developing themes, diversifying interdisciplinary analysis, as well as organizing curricular local components, among other options, within the domains of curricular autonomy.

In an attempt to tackle the problem of lengthy curricular documents, the EL aim at identifying the core set of contents, skills and attitudes in each subject and in each school year, so as to fulfill the following objectives: to effectively reinforce learnings; to develop skills which require more time (to carry out tasks which involve research, analysis, debate and reflection); and to enable effective pedagogical differentiation in the classroom.

The EL were built upon the existing curricular documents (i.e. the Curricular Aims-Metas Curriculares - and the syllabi for all subjects), which remain in force. Also, the EL were based on other supporting documents such as the CEFR and the European Language Portfolio. Essentially, the EL were designed based on three concepts - knowledge, skills and attitudes - throughout the curricular advancement, expressing:

(a) what students should know (the contents of the structured subject knowledge which are essential, conceptually articulated, relevant and meaningful);

(b) the cognitive processes which students must activate so as to acquire that knowledge (necessary learning operations/actions);

for Secondary Education were approved in August 2018. Further details available at: <www.dge.mec.pt/aprendizagens-essenciais-ensino-secundario>. Access: March 18, 2019. 
(c) the know-how (how students show they have learned) in a given subject (in its specificity and in the horizontal link among the knowledge in several subjects) and in a given school year.

All these three components are integrated in the cycle of study and regarded in their continuity and vertical link, throughout compulsory education. The EL documents are structured in the following way: (a) introduction; (b) identification of the 10 areas of competences of the Students Profile; and (c) operationalization of the EL (with 4 identifiers: domains; knowledge, skills and attitudes; strategic teaching actions oriented towards the Students Profiles; descriptors of the Students Profiles).

The analysis carried out for this study focused on the third part of the document, the operationalization of the EL, more specifically, on the identification of the domains, the thematic or situational areas, the competences (communicative, intercultural and strategic), and the knowledge, skills and attitudes.

It is noteworthy, though, to refer to the introductory text, common to the EL documents for all school years:

The learning of a foreign language (...) also means the construction of a selfidentity of a global citizen in the relationship with the others, based on attitudes and values, as well as respect for the other and, within the specific scope of the English language, for the Anglo-Saxon ${ }^{6}$ culture, and all other cultures of the world, responsibility and cooperation among individuals and peoples, with individual and collective impact.

It is remarkable that, although there is a distinct reference to the native culture (Anglo-Saxon), the text expands the view of interculturality towards "all other cultures of the world"

The following is the analysis carried out of the EL documents for Years 3 to 12 in an attempt to identify the concepts of ICC and ELF and how they are introduced and developed.

6 The term Anglo-Saxon is used in these documents meaning English-speaking countries. 


\section{ANALYSIS OF THE EL DOCUMENTS}

This section aims at identifying the references to the development of intercultural communicative competence and ELF in the Essential Learnings documents in each year of basic and secondary education:

Year 3:

Domain: Intercultural Competence

- Recognize different cultural realities: recognize basic characteristics of the Anglo-Saxon culture (p. 7)

Domain: Strategic Competence

- Use technological literacy to communicate and have access to knowledge in a given context: communicate (in a simple manner) with others, in a local, national and international context, (resorting to technological applications for online production and communication) (p. 8) (this skill is repeated in all school years)

\section{Year 4:}

Strategic teaching actions oriented towards the Students Profiles (Examples of actions to be developed in the subject):

- Promote strategies that require/lead students to: compare different ideas and perspectives on a given problem and/or a way to solve it, taking into account, for example, different cultural perspectives, whether local, national or global (p. 6)

Domain: Intercultural Competence

- Recognize different intercultural realities: recognize elements of AngloSaxon culture

- Suggestion of topics to be developed: identify festivities and related activities in different parts of the world (p. 8)

\section{Year 5:}

Strategic teaching actions oriented towards the Students Profiles (Examples of actions to be developed in the subject):

- Promote strategies that require/lead students to: respect different cultural perspectives (beliefs or opinions) (p. 6)

Domain: Intercultural Competence

- Recognize different intercultural realities: recognize the constituent elements of the students' own culture and the culture(s) of the foreign language: identify places of different cultural realities (the community of others); locate some English-speaking countries on a map; relate capitals and some cities to those countries; recognize cultural aspects of English-speaking countries, such as flags and national symbols (p. 7)

- Suggestion of topics to be developed: members of the British royal family (p. 8) 


\section{Year 6:}

Strategic teaching actions oriented towards the Students Profiles (Examples of actions to be developed in the subject):

- Promote strategies that require/lead students to: respect different cultural perspectives (beliefs or opinions) (p. 6)

Domain: Intercultural Competence

- Recognize different intercultural realities: learn about the students' and the others' environment so as to identify the cultural diversity in different territories; describe different elements of own culture, identity and language as opposed to the Anglo-Saxon culture and the English language; compare the surrounding spaces to those in different cultural realities; identify concrete examples of attitudes of tolerance and intercultural respect; recognize some differences in intercultural relations (p. 7)

\section{Year 7:}

Domain: Intercultural Competence

- Recognize different intercultural realities: talk about leisure activities in the students' cultural environment as opposed to those in other cultures, including the Anglo-Saxon; recognize, understand and explain concrete examples of attitudes of tolerance and intercultural respect (p. 5-6)

- Suggestion of topics to be developed: recognize the difference between Great Britain and the United Kingdom and identify the constitution of the United Kingdom; identify some important states and cities in the United States of America and some countries in the European Union; compare family households, types of housing and festivities in different countries ( $p$. 7)

Strategic teaching actions oriented towards the Students Profiles (Examples of actions to be developed in the subject):

- Promote strategies that require/lead students to: compare different ideas and perspectives on a given problem and/or a way to solve it, taking into account, for example, different cultural perspectives, whether local, national or global (p. 7) (this skill is repeated in all the following school years)

\section{Year 8:}

\section{Domain: Intercultural Competence}

- Recognize different intercultural realities: learn about some cultural aspects of several English-speaking countries (p. 7)

\section{Year 9:}

Domain: Intercultural Competence

- Recognize different intercultural realities: learn about characters and celebrated works from English-speaking countries; learn about diversified cultural worlds; identify and comment on some factors that hinder intercultural communication (p. 7) 


\section{Year 10:}

\section{Domain: Intercultural Competence}

-Recognize different intercultural realities: develop awareness of own sociocultural circle and how it relates to the cultural circles of others; relate the students' cultural background to other cultures they get in contact with, putting their points of view and systems of cultural values into perspective, demonstrating ability to question attitudes that stereotype other peoples, societies and cultures (p. 7)

\section{Year 11:}

"With regard to Year 11 English (level B2), the student should be able to (...) communicate with a degree of spontaneity and ease with native speakers (...)." (Adapted from CEFR, global scale, Level B2: Independent user; Council of Europe, 2001) (Introductory text, p. 2)

Thematic/situational areas:

4. A World of Many Cultures: Diversity in English-speaking cultures; The multicultural society, social action and volunteering movements and organizations (p. 4)

Domain: Communicative Competence

- Listening comprehension: progressively interact with the diversity of the English language in international contexts of use, involving speakers of different cultures (p. 5)

Domain: Intercultural Competence

- Recognize different intercultural realities: show ability for intercultural communication and openness towards new experiences and ideas, in the face of other societies and cultures; express interest in learning about those cultures; relate the students' cultural background to the cultures they get in contact with, putting their points of view and systems of cultural values into perspective; demonstrate ability to question attitudes that stereotype peoples, societies and cultures; develop attitudes and civic and ethical values which support multicultural understanding and interaction; expand knowledge about the sociocultural environment of English-speaking countries (pp. 7-8) (this skill is repeated in Year 12)

\section{Year 12:}

"With regard to Year 12 English (B2.1/B2.2), the student should be able to (...) communicate with a degree of spontaneity and ease with native speakers, without strain for either party (...)." (Adapted from CEFR, global scale, Level B2.1/B2.2: Independent user; Council of Europe, 2001) (Introductory text, p. 2)

Thematic/situational areas:

1. The English Language in the World: Development of the English language as a social, political and cultural phenomenon; Diversity of the English language

2. Citizenship and Multiculturalism: The Universal Declaration of Human Rights; Living with diversity 
4. Cultures, Arts and Society: Literature, cinema and music in the second half of the 20th century; Diversity of voices in English-speaking countries (p. 4) Domain: Communicative Competence

- Listening comprehension: interact with the diversity of the English language in international contexts of use, involving speakers of different cultures (p. 5)

\section{DISCUSSION}

Based on the references to "Anglo-Saxon cultures" as well as "other cultures of the world", it is clear that the introductory text common to the EL documents for all school years (3 to 12) sets the tone for the overall approach to intercultural communication in the EL. On the one hand, it exhibits a conservative, traditional perspective which emphasizes English-speaking cultures in ELT while, on the other hand, it displays a more inclusive and international viewpoint as it considers any other culture where English is used as an international lingua franca.

Except for Year 10, all documents make specific reference to Anglo-Saxon or English-speaking cultures/countries. More specifically, in the Year 5 document, the only topic suggested to be developed is "members of the British royal family" (p. 8). Likewise, the topics suggested in the Year 7 EL explicitly refer to the recognition of "the difference between Great Britain and the United Kingdom (...) and the constitution of the United Kingdom; (and) (...) some important states and cities in the United States of America" (p. 7).

Conversely, some documents suggest an international and multicultural approach in the 'strategic teaching actions oriented towards the Students Profiles' (Years 4, 7, 8, 9, 10, 11 and 12) when they propose to adopt "different cultural perspectives, whether local, national or global." Similarly, most documents refer to the use of "technological literacy to (...) communicate with others, in a local, national and international/global context" in the Strategic Competence section (only Years 5 and 6 do not make direct reference to a 'local, national and international context'). It is interesting to point out that the topic suggested to be developed in Year 4 is to "identify festivities and related activities in different parts of the world." Another curious reference is made in the Year 7 document, when it recommends that students should "recognize different intercultural realities" by talking "about leisure activities in the students' cultural environment as opposed to those in other cultures, including the Anglo-Saxon" 
(p. 6). Finally, it is quite relevant to mention the overall multicultural approach of the Year $10 \mathrm{EL}$. There is no reference to Anglo-Saxon or English-speaking cultures but it refers to "the cultural circles of others", "other cultures", "other peoples, societies and cultures" (p. 7), as well as the references to "different cultural perspectives, whether local, national or global" in the strategic actions and the communication "in a local, national and international context" in the Strategic Competence, as noted above.

The documents analyzed also display some remarkable features. As observed in the introductory text common to all EL, most documents (Years 4, 5, $6,7,8,9,11$ and 12) incorporate a traditional approach to culture in ELT emphasizing the English-speaking cultures although at the same time allowing for a more multicultural and intercultural view. Also, some documents propose the development of intercultural (communicative) competence (besides the general reference to 'Intercultural Competence' and its main aim: to recognize different cultural realities) as in Year 6 ("identify concrete examples of attitudes of tolerance and intercultural respect; recognize some differences in intercultural relations", p. 7), Year 9 ("identify and comment on some factors that hinder intercultural communication", p. 7), and Years 11 and 12 ("show ability for intercultural communication and openness towards new experiences and ideas, in the face of other societies and cultures", Year 11, p. 7; Year 12, p. 7).

Another interesting point is the reference to awareness of the local culture, which is made in most documents except for Years 8 and 9. However, it becomes clear that only in secondary education (Years 10, 11 and 12) the development of the students' intercultural communicative competence is truly fostered. To enhance this, the aims of the Communicative Competence for listening comprehension skills reinforce an international perspective of the learning and use of English. Both in Years 11 and 12, the EL recommend that learners should "(progressively) interact with the diversity of the English language in international contexts of use, involving speakers of different cultures" (Year 11, p. 5; Year 12, p. 5).

Nevertheless, these documents seem to maintain a native-oriented paradigm which reinforces the traditional view of ELT when it suggests that the aim of language use should be to "communicate with a degree of spontaneity and ease with native speakers (without strain for either party)" (Year 11, p. 2; Year 12, p. 2), disregarding the overwhelming majority of non-native speaker communicative interactions in international contexts. 


\section{CONCLUDING REMARKS}

The purpose of this study was to determine if the concepts of ICC and ELF are theoretically and practically put forward in some of the most recently composed European and Portuguese ELT documents and, if so, how they were presented and framed to be employed in the English language classroom. As for the Essential Learnings documents newly proposed by the Portuguese Ministry of Education as guiding principles in teaching and learning English in Basic and Secondary education, the analysis of those documents showed that even though they incorporate the development of the learners' Intercultural Competence in all years of education, the fundamental notions of ICC and ELF are not quite consistently laid down. If, on the one hand, some documents promote the acquisition of skills, attitudes and behavior based on the learning and use of English as an international lingua franca, involving native and non-native speakers in multilingual and multicultural contexts, on the other hand, most documents continue to favor an approach that relates the English language to native norms, the native speaker and English-speaking cultures.

The use of some European documents, such as the CEFR and the $\mathrm{CEFR} / \mathrm{CV}$, as guidelines for the conception and implementation of the EL may have also contributed to the adoption of such theoretical and practical approach to ELT as both the CEFR and the CEFR/CV do not take into consideration what distinguishes the learning and teaching of the English language in the $21^{\text {st }}$ century from all other languages which is exactly its role as a global lingua franca. Fundamentally, any English language policy designed to foster the acquisition of intercultural communicative competence should not ignore the substantial changes the current use of English as a lingua franca has brought to the language classroom.

\section{REFERENCES}

ALPTEKIN, C. Towards intercultural communicative competence. ELT Journal, v. 56, no. 1, p. 57-64, 2002.

BAYYURT, Y.; SIFAKIS, N. ELF-aware in-service teacher education: a transformative perspective. In: BOWLES, H; COGO, A. (Eds.). International perspectives on English as a Lingua Franca: pedagogical insights. New York: Palgrave Macmillan, 2015a, p. 117-135. 
BAYYURT, Y.; SIFAKIS, N. Developing an ELF-aware pedagogy: insights from a selfeducation programme. In: VETTOREL, P. (Ed.). New Frontiers in Teaching and Learning English. Newcastle upon Tyne: Cambridge Scholars Publishing, 2015b, p. 55-76.

BYRAM, M. Teaching and assessing intercultural communicative Competence. Clevedon: Multilingual Matters, 1997.

BYRAM, M.; MORGAN, C. Teaching-and-Learning Language and Culture. Clevedon: Multilingual Matters, 1994.

COGO, A.; DEWEY, M. Analysing English as a Lingua Franca: A corpus-based investigation. London: Continuum, 2012.

CORTAZZI, M.; JIN, L. X. Cultural mirrors: Materials and methods in the EFL classroom. In: HINKEL, E. (Ed.). Culture in second language teaching and learning. Cambridge: Cambridge University Press, 1999, p. 196-219.

COUNCIL OF EUROPE. Common European Framework of Reference for Languages: Learning, teaching, assessment. Cambridge: Cambridge University Press, 2001.

COUNCIL OF EUROPE. Common European Framework of Reference for Languages: Learning, teaching, assessment. Companion volume with new descriptors, 2018.

FIRTH, A. The discursive accomplishment of normality. On 'lingua franca' English and conversation analysis. Journal of Pragmatics, no.. 26, p. 237-259, 1996.

GRADDOL, D. The future of English? London: The British Council, 1997.

GUERRA, L.; BAYYURT, Y. A review of research on the influence of English as a Lingua Franca on English language teaching. In: EKŞI, G. Y.; GUERRA, L.; WERBIŃSKA, D.; BAYYURT, Y. (Eds.). Research trends in English language teacher education and English language teaching. Évora: University of Évora, 2019, p. 363-384.

GUERRA, L.; GONÇALVES, O. Studies in intercultural communicative competence in language teacher education. In: EKŞI, G. Y.; GUERRA, L.; WERBIŃSKA, D.;

BAYYURT, Y. (Eds.). Research trends in English language teacher education and English language teaching. Évora: University of Évora, 2019, p. 401-419.

HOUSE, J. Misunderstanding in intercultural communication: Interactions in English as a lingua franca and the myth of mutual intelligibility. In: GNUTZMANN, C. (Ed.). Teaching and learning English as a Global Language: Native and non-native perspectives. Tübingen: Stauffenberg Verlag, 1999, p. 73-89.

JENKINS, J. English as a Lingua Franca in the international university: The politics of academic English language policy. London \& New York: Routledge, 2013. 
KURT, Y; CAVALHEIRO, L.; PEREIRA, R. Studies on ELF-awareness in English language teacher Education. In: EKŞI, G. Y.; GUERRA, L.; WERBIŃSKA, D.; BAYYURT, Y. (Eds.). Research trends in English language teacher education and English language teaching. Évora: University of Évora, 2019, p. 433-448.

LWIN, S. M.; MARLINA, R. Using folktales as a way to operationalise the paradigm of teaching English as an International Language. Asian Englishes, v. 20, no. 3, p. 206-219, 2018.

MAURANEN, A. Exploring ELF: Academic English shaped by non-native speakers. Cambridge: Cambridge University Press, 2012.

MAURANEN, A. Conceptualising ELF. In: JENKINS, J.; BAKER, W; DEWEY, M. (Eds.). The Routledge handbook of English as a Lingua Franca. London \& New York: Routledge, 2018, p. 7-24.

MUGHAN, T. Intercultural competence for foreign languages students in higher education. The Language Learning Journal, no. 20, p. 59-65, 1999.

OLIVEIRA, C. R.; GOMES, N. Indicadores de integração de imigrantes: relatório estatístico anual 2017. Lisboa: Observatório das Migrações, 2017.

PITZL, M.-L. Creativity meets convention: Idiom variation and remetaphorization in ELF. Journal of English as a Lingua Franca, v. 1, no. 1, p. 27-55, 2012.

REID, E. Status of intercultural education in English language learning and in foreign language teacher training. XLinguae, v. 7, no. 4, p. 43-54, 2014.

SEIDLHOFER, B. Understanding English as a Lingua Franca. Oxford: Oxford University Press, 2011.

SHUANG, L. Rethinking intercultural competence: Global and local nexus, Journal of Multicultural Discourses, v. 7, no. 3, p. 269-275, 2012.

SIFAKIS, N. ELF awareness in English language teaching: principles and processes. Applied Linguistics, v. 40, no. 2, p. 1-20, 2017.

SIFAKIS, N.; BAYYURT, Y. Insights from ELF and WE in teacher training in Greece and Turkey. World Englishes, v. 34, no. 3, p. 471-484, 2015.

SIFAKIS, N.; LOPRIORE, L.; DEWEY, M.; BAYYURT, Y.; VETTOREL, P.;

CAVALHEIRO, L.; SIQUEIRA, S..; KORDIA, S. ELF-awareness in ELT: bringing together theory and practice. Journal of English as a Lingua Franca, v. 7, no. 1, p. 155-209, 2018. 
SPITZBERG, B.; CHANGNON, G. Conceptualizing intercultural competence. In:

DEARDORFF, D. K. (Ed.). The SAGE Handbook of Intercultural Competence. Thousand

Oaks: Sage, 2009, p. 2-52.

Luís Guerra is an Assistant Professor of English Language and Linguistics and the Director of the Language Centre of the School of Social Sciences, University of Evora, Portugal and has a PhD in English Language Teaching/Applied Linguistics from the University of Warwick, UK. He has extensive experience in ELT having taught in Brazil, the US, the UK, Spain and Portugal and has published books, book chapters and articles. His research interests are ELF/EIL, ELFbased teaching methodology, World Englishes in ELT, the role of English in the Expanding Circle, intercultural communicative competence, language learning motivation and the use of technology in second language teaching/learning.

Nota do editor: Artigo submetido para avaliação em: 14/03/2019. Aprovado em sistema duplo cego em: 17/11/2019. 